\title{
User Acceptance and Field Implementation of Decision Support Systems
}

\author{
Sharon L. Riedel
}

ARI Field Unit at Fort Leavenworth, Kansas Stanley M. Halpin, Chief

\section{Systems Research Laboratory Robin L. Keesee, Director}

U.S. ARMY RESEARCH INSTITUTE FOR THE BEHAVIORAL AND SOCIAL SCIENCES 5001 Eisenhower Avenue, Alexandria, Virginia 22333-5600

Office, Deputy Chief of Staff for Personnel

Department of the Army

$$
\text { May } 1988
$$

